\title{
Efficiency of Chemical Ripener Action in Sugarcane. I. Growth and Quality Responses to Polaris Applied at Different Hours of the Day ${ }^{1}$
}

\author{
Alex G. Alexander ${ }^{2}$
}

\begin{abstract}
Immature sugarcane propagated by sand culture was treated with a single concentration of Polaris ${ }^{3}$ (N,N-bis [phosphonomethyl] glycine) at different hours of the day. Plants harvested 21 days thereafter showed significant growth and qualitative differences relating to the amount of sunlight received prior to chemical application. Ripening efficiency was progressively improved as the treatment time was delayed from 0630 to $1630 \mathrm{~h}$. Growth repression was decreased as treatment time was delayed from 0630 to $1830 \mathrm{~h}$. These trends were not appreciably altered by darkening the plants throughout the following day. Preillumination effects are tentatively explained in terms of a Polaris-stimulated transport of hormone-like substances diurnally activated or depleted in leaves. Tissue sucrose levels and acid invertase were extremely sensitive to Polaris but not to the hour of its reception. Foliar trehalase was increased by Polaris and further increased by applying it later in the day.
\end{abstract}

\section{INTRODUCTION}

Although various plant growth regulators have shown ripening potential in sugarcane $(6,8,10)$, chemical ripeners offering consistent and predictable quality improvement have long eluded the sugarcane scientist. This is due in part to the use of essentially fixed methods to screen numerous and chemically discrete compounds with a view toward identifying one with inherent answers to the varietal, cultural, and climatic variables of a regional industry.

Equally important is the definition of treatment conditions needed for a candidate ripener to operate with optimal efficiency. For example, very little is known about the importance of incident sunlight intensity or the illumination periods preceding and following chemical application. In Puerto Rico, applications by aircraft are commonly given at an early-

${ }^{1}$ Manuscript submitted to Editorial Board August 29, 1975.

${ }^{2}$ Plant Physiologist, Agricultural Experiment Station, University of Puerto Rico, Mayagüez Campus, Río Piedras, P.R.

${ }^{3}$ Trade names are used in this publication solely for the purpose of providing specific information. Mention of a trade name does not constitute a guarantee or warranty of equipment or materials by the Agricultural Experiment Station of the University of Puerto Rico or an endorsement over other equipment or materials not mentioned. 
morning hour when air movement is minimal. Plot treatments by ground equipment or manual sprayers may extend throughout most of the day, depending on the quantity and condition of the test cane and the availability of labor.

The contributions of light toward the regulation of physiological processes in higher plants are increasingly recognized (2). The effectiveness of certain agricultural chemicals appears to depend upon sunlight intensity $(1,9)$. Recent findings suggest that growth-regulator action in sugarcane leaves may relate to the quality of incident radiation (4). The studies described herein report the influence of Polaris ${ }^{4}$ on cane growth and quality as affected by the time of day of chemical reception.

\section{MATERIALS AND METHODS}

One-eye cuttings of the interspecific hybrid PR 980 were propagated in the greenhouse using controlled water and nutrient regimes in quartz sand as previously described (3). At 12 weeks of age, test plants were sprayed until runoff with an aqueous $0.3 \%$ Polaris solution containing $0.10 \%$ Tween 20 as wetting agent. Application times were varied diurnally, i.e., at $0630,1230,1630$, and $1830 \mathrm{~h}$. Solar radiation values were recorded at 30 -min intervals with a Weston light meter. The diurnal radiation curve together with application intervals for the day of treatment, February 20, is illustrated graphically in figure 1.

The 0630 and $1830 \mathrm{~h}$ treatments generally corresponded to first light and evening twilight, respectively. ${ }^{5}$ A second set of plants treated at 1830 $\mathrm{h}$ were moved to a darkroom and excluded from light for $36 \mathrm{~h}$, that is, through the subsequent night and the following day and night. Control plants were sprayed with distilled water and wetting agent at $0630 \mathrm{~h}$. There were three replications.

Sugarcane samples consisting of six uniform plants per replicate were harvested at 0 days, i.e., just prior to the $0630 \mathrm{~h}$ application, and at 21 days thereafter. Green weight measurements were taken for whole plants, tops, and millable stalks. Appropriate leaf, stem, and immature storage tissues were frozen for sucrose, juice quality, and enzyme analyses as previously described (3). All replicated data were submitted to statistical analysis by the Duncan New Multiple Range Test.

\section{RESULTS}

Symptoms of foliar discoloration and desiccation characteristic of Polaris developed in all plants treated with the chemical. The intensity of chemical injury was visibly lessened in plants darkened for 12 or $36 \mathrm{~h}$ immediately after treatment (table 1 , treatments 5 and 6).

\footnotetext{
${ }^{4} \mathrm{~N}, \mathrm{~N}$-bis (phosphonomethyl) glycine, a product of the Monsanto Agricultural Products
} Co.

${ }^{5}$ The sun rose at $0649 \mathrm{~h}$ and set at $1827 \mathrm{~h}$. The day was virtually cloudless. 
Parameters reflecting long-term effects of ripener action, including growth (table 2) and juice quality (table 3), were generally sensitive to the time of day of chemical reception. A severe growth restriction produced by the early-morning treatment was progressively lessened as treatment time was delayed up to $1830 \mathrm{~h}$ (table 2). Brix and polarization values for milled juice increased as treatment time was delayed up to

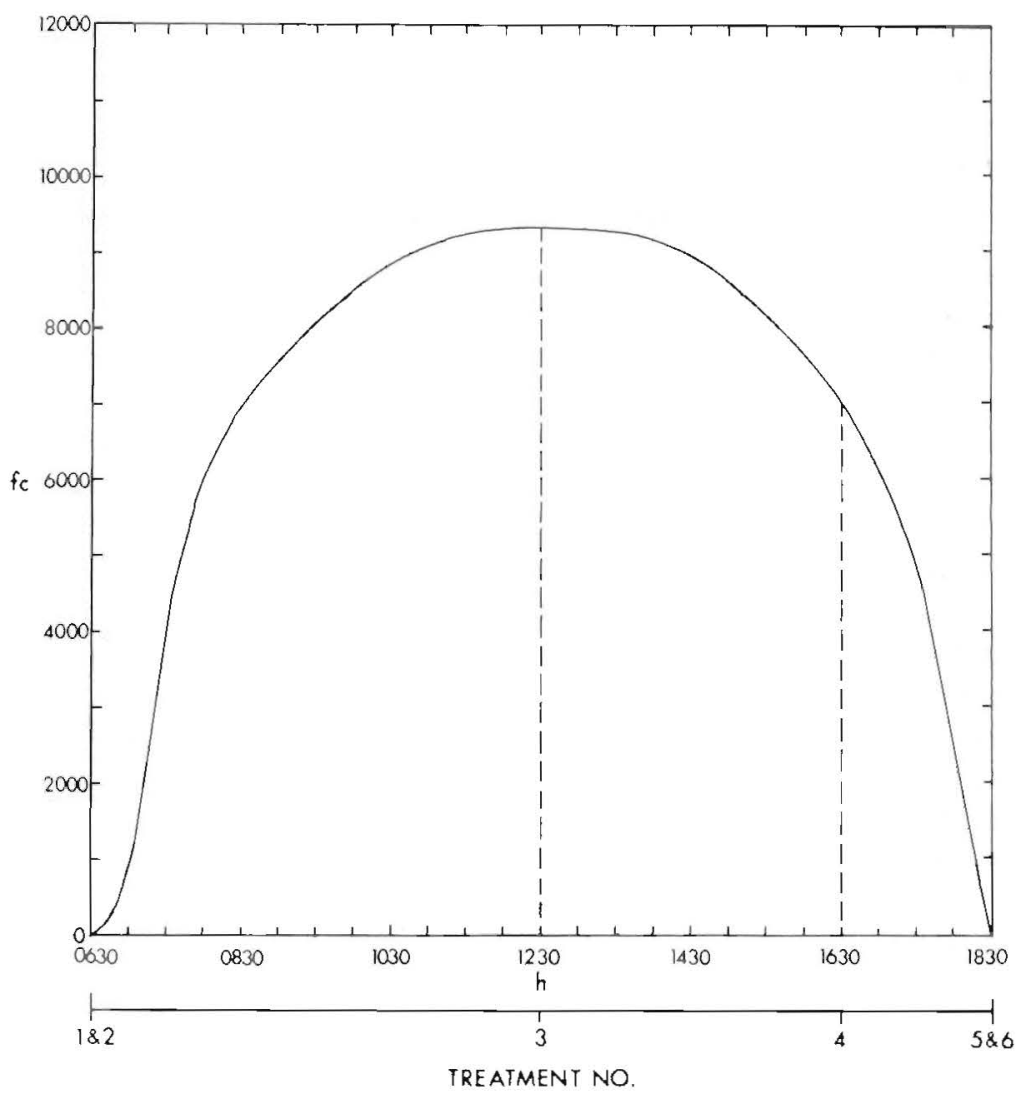

Fig. 1.-Diurnal solar radiation values and times of Polaris application, Río Piedras, February 20, 1975. The sun rose at $0649 \mathrm{~h}$ and set at $1827 \mathrm{~h}$.

$1630 \mathrm{~h}$ (table 3). Neither growth nor juice-quality changes were appreciably altered by darkening the plants throughout the following day. The diurnal trends attained statistical significance, at 21 days, for total green weight and brix. Polarization increases were significant from $1230 \mathrm{~h}$ onward.

Parameters having natural diurnal variability, such as leaf and meristem sucrose (table 4), and acid invertase (table 5), were very 
TABLE 1.-Numerical ratings for leaf injury symptoms in immature sugarcane treated with Polaris at different hours of the day:

\begin{tabular}{cccc}
\hline $\begin{array}{c}\text { Treatment } \\
\text { number }\end{array}$ & Treatment & Hour & $\begin{array}{c}\text { Numerical } \\
\text { rating }^{2}\end{array}$ \\
\hline 1 & Control & 0630 & \\
2 & Polaris & 0630 & 4.6 \\
3 & " & 1230 & 4.3 \\
4 & " & 1630 & 4.0 \\
5 & " & 1830 & 3.3 \\
6 & & $1830^{3}$ & 2.6 \\
\hline
\end{tabular}

${ }^{1}$ Plants were rated by visual inspection 20 days after treatment.

${ }^{2}$ On a scale 0 to $5: 0=$ no symptoms; 5 = general yellowing and desiccation.

${ }^{3}$ Plants were retained in darkness throughout the following day.

TABLE 2.-Growth responses of immature sugarcane treated with Polaris at different hours of the day

\begin{tabular}{|c|c|c|c|c|c|c|c|c|}
\hline \multirow{3}{*}{$\begin{array}{l}\text { Treat- } \\
\text { ment } \\
\text { num- } \\
\text { ber }\end{array}$} & \multirow{3}{*}{ Treatment } & \multirow{3}{*}{ Hour } & \multicolumn{6}{|c|}{ Green wt changes ( $\mathrm{g} / \mathrm{plant}$ ) from 0 to 21 days for- } \\
\hline & & & \multicolumn{2}{|c|}{$\begin{array}{l}\text { Total green } \\
\text { weight }\end{array}$} & \multicolumn{2}{|c|}{ Top weight } & \multicolumn{2}{|c|}{ Stem weight } \\
\hline & & & 0 & 21 & 0 & 21 & 0 & 21 \\
\hline 1 & Control & 0630 & $206 \mathrm{a}^{1}$ & $268 \mathrm{a}$ & $143 \mathrm{a}$ & $178 \mathrm{a}$ & $62.7 \mathrm{a}$ & $90.0 \mathrm{a}$ \\
\hline 2 & Polaris & 0630 & $199 \mathrm{a}$ & $183 \mathrm{~b}$ & $136 \mathrm{a}$ & $115 \mathrm{~b}$ & $63.0 \mathrm{a}$ & $68.4 \mathrm{a}$ \\
\hline 3 & " & 1230 & $195 \mathrm{a}$ & $196 \mathrm{~b}$ & $132 \mathrm{a}$ & $121 b$ & $63.3 \mathrm{a}$ & $74.4 \mathrm{a}$ \\
\hline 4 & “ & 1630 & $204 \mathrm{a}$ & $211 \mathrm{~b}$ & $142 \mathrm{a}$ & $125 \mathrm{~b}$ & $62.0 \mathrm{a}$ & $85.6 \mathrm{a}$ \\
\hline 5 & " & 1830 & $181 \mathrm{a}$ & $219 a b$ & $126 \mathrm{a}$ & $130 b$ & $55.0 \mathrm{a}$ & $89.0 \mathrm{a}$ \\
\hline 6 & " & $1830^{2}$ & $202 \mathrm{a}$ & $226 \mathrm{ab}$ & $141 \mathrm{a}$ & $130 \mathrm{~b}$ & $60.7 \mathrm{a}$ & $96.0 \mathrm{a}$ \\
\hline
\end{tabular}

${ }^{1}$ Mean values in the same column bearing unlike letters differ significantly $(P<.05)$.

${ }^{2}$ Plants were retained in darkness throughout the following day.

TABLE 3. Brix and polarization values for immature sugarcane treated with Polaris at different hours of the day

\begin{tabular}{|c|c|c|c|c|c|c|}
\hline \multirow{3}{*}{$\begin{array}{l}\text { Treatment } \\
\text { number }\end{array}$} & \multirow{3}{*}{ Treatment } & \multirow{3}{*}{ Hour } & \multicolumn{4}{|c|}{ Means values at 0 and 21 days for- } \\
\hline & & & \multicolumn{2}{|c|}{ Brix } & \multicolumn{2}{|c|}{ Polarization } \\
\hline & & & 0 & 21 & 0 & 21 \\
\hline 1 & Control & 0630 & $8.4 \mathrm{a}^{1}$ & $9.8 \mathrm{a}$ & $16.3 \mathrm{a}$ & $19.5 \mathrm{a}$ \\
\hline 2 & Polaris & 0630 & $9.3 \mathrm{a}$ & $13.7 \mathrm{~b}$ & $17.6 \mathrm{a}$ & $30.7 \mathrm{ab}$ \\
\hline 3 & ، & 1230 & $8.4 \mathrm{a}$ & $14.9 \mathrm{bc}$ & $15.4 \mathrm{a}$ & $40.1 \mathrm{~b}$ \\
\hline 4 & ، & 1630 & $7.2 \mathrm{a}$ & $16.2 \mathrm{c}$ & $11.7 \mathrm{a}$ & $43.8 \mathrm{~b}$ \\
\hline 5 & “ & 1830 & $7.1 \mathrm{a}$ & $14.4 \mathrm{bc}$ & $11.0 \mathrm{a}$ & $38.4 \mathrm{~b}$ \\
\hline 6 & ، & $1830^{2}$ & $8.2 \mathrm{a}$ & $14.6 \mathrm{bc}$ & $11.8 \mathrm{a}$ & $41.4 \mathrm{~b}$ \\
\hline
\end{tabular}

${ }^{1}$ Mean values in the same column bearing unlike letters differ significantly $(\mathrm{P}<.05)$.

${ }^{2}$ Plants were retained in darkness throughout the following day. 
TABLE 4.-Sugar content of immature sugarcane treated with Polaris at different hours of the day

\begin{tabular}{|c|c|c|c|c|c|}
\hline \multirow{3}{*}{ Treatment } & \multirow{3}{*}{ Hour } & \multicolumn{4}{|c|}{$\mathrm{Mg}$ sugar/g of lyophilized tissue, at 0 and 21 days- } \\
\hline & & \multicolumn{2}{|c|}{ Sucrose } & \multicolumn{2}{|c|}{ Total reducing } \\
\hline & & 0 & 21 & 0 & 21 \\
\hline \multicolumn{6}{|c|}{ Leaf tissue } \\
\hline Control & 0630 & $47.3 \mathrm{a}^{1}$ & $55.4 \mathrm{a}$ & $14.9 \mathrm{a}$ & $14.0 \mathrm{a}$ \\
\hline Polaris & 0630 & $46.4 \mathrm{a}$ & $98.8 \mathrm{~b}$ & $14.7 \mathrm{a}$ & $19.2 \mathrm{~b}$ \\
\hline “ & 1230 & $51.6 \mathrm{a}$ & $105.9 \mathrm{~b}$ & $15.7 \mathrm{a}$ & $21.6 \mathrm{~b}$ \\
\hline “. & 1630 & $47.7 \mathrm{a}$ & $105.8 \mathrm{~b}$ & $14.3 \mathrm{a}$ & $19.8 \mathrm{~b}$ \\
\hline “ & 1830 & 49.9 a & $104.1 \mathrm{~b}$ & $14.1 \mathrm{a}$ & $22.2 \mathrm{~b}$ \\
\hline “ & $1830^{2}$ & $53.0 \mathrm{a}$ & $107.7 \mathrm{~b}$ & $14.2 \mathrm{a}$ & $22.8 \mathrm{~b}$ \\
\hline \multicolumn{6}{|c|}{ Immature storage tissue } \\
\hline Control & 0630 & $91.8 \mathrm{a}$ & $87.8 \mathrm{a}$ & $39.0 \mathrm{a}$ & $37.5 \mathrm{a}$ \\
\hline Polaris & 0630 & $84.8 \mathrm{a}$ & $255.0 \mathrm{~b}$ & $42.3 \mathrm{a}$ & $20.6 \mathrm{bc}$ \\
\hline ، & 1230 & $96.8 \mathrm{a}$ & $274.0 \mathrm{~b}$ & $40.1 \mathrm{a}$ & $22.2 \mathrm{bc}$ \\
\hline “ & 1630 & $92.4 \mathrm{a}$ & $275.0 \mathrm{~b}$ & $40.7 \mathrm{a}$ & $17.9 \mathrm{c}$ \\
\hline ." & 1830 & $92.7 \mathrm{a}$ & $260.6 \mathrm{~b}$ & $39.9 \mathrm{a}$ & $24.6 \mathrm{~b}$ \\
\hline .. & $1830^{2}$ & $87.2 \mathrm{a}$ & $263.7 \mathrm{~b}$ & $42.0 \mathrm{a}$ & $24.9 \mathrm{~b}$ \\
\hline
\end{tabular}

${ }^{1}$ Mean values in the same column bearing unlike letters differ significantly $(\mathrm{P}<.05)$.

${ }^{2}$ Plants were retained in darkness throughout the following day.

TABLE 5.-Enzymic responses for immature sugarcane treated with Polaris at different hours of the day

\begin{tabular}{|c|c|c|c|c|c|c|c|c|c|}
\hline \multirow{3}{*}{ Treatment } & \multirow{3}{*}{ Hour } & \multicolumn{8}{|c|}{$\mathrm{Mg}$ product/g of lyophilized tissue, at 0 and 21 days, for enzyme- } \\
\hline & & \multicolumn{2}{|c|}{ Acid phosphatase } & \multicolumn{2}{|c|}{ ATP-ase } & \multicolumn{2}{|c|}{$\beta$-amylase } & \multicolumn{2}{|c|}{ Trehalase } \\
\hline & & 0 & 21 & 0 & 21 & 0 & 21 & 0 & 21 \\
\hline \multicolumn{10}{|c|}{ Leaf tissue } \\
\hline Control & 0630 & $1.8 \mathrm{a}^{1}$ & $1.6 \mathrm{a}$ & $4.5 \mathrm{a}$ & $3.6 \mathrm{a}$ & $190 \mathrm{a}$ & $211 \mathrm{a}$ & $0.67 \mathrm{a}$ & $0.73 \mathrm{~b}$ \\
\hline Polaris & 0630 & $1.1 \mathrm{a}$ & $1.6 \mathrm{a}$ & $4.0 \mathrm{a}$ & $3.3 \mathrm{a}$ & $199 \mathrm{a}$ & $175 \mathrm{~b}$ & $.73 \mathrm{a}$ & $1.13 \mathrm{ab}$ \\
\hline “ & 1230 & $1.8 \mathrm{a}$ & $1.6 \mathrm{a}$ & $4.6 \mathrm{a}$ & $4.2 \mathrm{a}$ & $177 \mathrm{a}$ & $157 \mathrm{~b}$ & $.67 \mathrm{a}$ & $1.50 \mathrm{a}$ \\
\hline “ & 1630 & $1.3 \mathrm{a}$ & $1.7 \mathrm{a}$ & $4.0 \mathrm{a}$ & $4.0 \mathrm{a}$ & $191 \mathrm{a}$ & $157 \mathrm{~b}$ & $.83 \mathrm{a}$ & $1.63 \mathrm{a}$ \\
\hline “. & 1830 & $1.7 \mathrm{a}$ & $1.7 \mathrm{a}$ & $4.6 \mathrm{a}$ & $3.8 \mathrm{a}$ & $164 \mathrm{a}$ & $159 \mathrm{~b}$ & $.63 \mathrm{a}$ & $1.40 \mathrm{a}$ \\
\hline “ & $1830^{2}$ & $1.8 \mathrm{a}$ & $1.8 \mathrm{a}$ & $4.4 \mathrm{a}$ & $3.6 \mathrm{a}$ & $159 \mathrm{a}$ & $164 \mathrm{~b}$ & $.70 \mathrm{a}$ & $.80 \mathrm{~b}$ \\
\hline \multicolumn{10}{|c|}{ Immature storage tissue } \\
\hline \multicolumn{10}{|c|}{ Acid invertase } \\
\hline Control & 0630 & $10.9 \mathrm{a}$ & $14.8 \mathrm{a}$ & $16.0 \mathrm{a}$ & $17.2 \mathrm{a}$ & $597 \mathrm{a}$ & $618 \mathrm{a}$ & $2.05 \mathrm{a}$ & $2.07 \mathrm{a}$ \\
\hline Polaris & 0630 & $10.7 \mathrm{a}$ & $.8 \mathrm{~b}$ & $15.8 \mathrm{a}$ & $11.2 \mathrm{~b}$ & $625 \mathrm{a}$ & $504 \mathrm{~b}$ & $1.77 \mathrm{a}$ & $.11 \mathrm{~b}$ \\
\hline “ & 1230 & $9.2 \mathrm{a}$ & $.1 \mathrm{c}$ & $15.4 \mathrm{a}$ & $12.1 \mathrm{~b}$ & $550 \mathrm{a}$ & $438 \mathrm{~b}$ & $1.00 \mathrm{a}$ & $.03 \mathrm{~b}$ \\
\hline “ & 1630 & $9.9 \mathrm{a}$ & $.2 \mathrm{c}$ & $15.4 \mathrm{a}$ & $11.7 \mathrm{~b}$ & 556 a & $428 \mathrm{~b}$ & $1.96 \mathrm{a}$ & $.09 \mathrm{~b}$ \\
\hline ، & 1830 & $10.7 \mathrm{a}$ & $.1 \mathrm{c}$ & $16.1 \mathrm{a}$ & $11.3 \mathrm{~b}$ & $570 \mathrm{a}$ & $444 \mathrm{~b}$ & $1.39 \mathrm{a}$ & $.04 \mathrm{~b}$ \\
\hline “ & $1830^{2}$ & $10.0 \mathrm{a}$ & $.1 \mathrm{c}$ & $16.4 \mathrm{a}$ & $11.9 \mathrm{~b}$ & 567 a & $430 \mathrm{~b}$ & $2.20 \mathrm{a}$ & $.09 \mathrm{~b}$ \\
\hline
\end{tabular}

${ }^{1}$ Mean values in the same column bearing unlike letters differ significantly $(\mathrm{P}<.05)$.

${ }^{2}$ Plants were retained in darkness throughout the following day. 
severely altered by Polaris regardless of treatment hour. Sucrose was increased while acid invertase declined to a nil level in all treated plants. Trehalase was also severely repressed in the meristematic region, but was increased in leaves, the latter effect being sensitive to the hour of chemical application.

\section{DISCUSSION}

\section{LIGHT INVOLVEMENT IN POLARIS GROWTH AND RIPENING ACTION}

The long term effects of Polaris on cane growth and quality appear to involve two distinct contributions from light; an improvement of ripening efficiency through preillumination of recipient leaf tissues, and a reduction of growth-repressing efficiency by comparable preexposures to sunlight. Both contributions require at least $10 \mathrm{~h}$ for optimal effect. The theory that chemical ripening involves light-sensitive processes in source tissues that are spatially and biochemically removed from growth-regulatory processes in sink tissues (4) is strengthened by these findings.

It appears that light effects relevant to Polaris efficiency lie in the realm of "potentiation," that is, of changes brought about within leaf tissues prior to its penetration rather than to changes in its peformance afterward. In terms of brix, for example, denying the leaves $10 \mathrm{~h}$ of preillumination (table 3 , treatments 3 vs. 4) produced far greater restrictions than denying them the entire day following application (table 3, treatments 5 vs. 6). Alternately, with the exception of foliar trehalase (table 5), none of the parameters measured in this study were significantly altered by darkening the plants the entire day following Polaris application (tables 2-5).

There is mounting evidence that light contributes to the control of physiological processes in most species of higher plants, possibly all species containing red and far-red forms of phytochrome (7). Within Saccharum there is some evidence of sugar transport control by far-red light (5). While the latter effect was not appreciably altered by Polaris and gibberellin pretreatments (4), Polaris vastly increased transport efficiency in wavelengths of 520 to 600 nanometers, that is, in the blue-green to yellow region normally having but little influence on transport. On the other hand, the mediating pigment systems and the roles of absorbed solar energy in governing sugarcane ripening are totally unknown. For this reason the following interpretations are offered only for the purpose of establishing working hypotheses.

The improvement of ripening efficiency resulting from preillumination may reflect a greater efficiency of movement of hormone-like substances 
from leaf to stem tissues. The theory of mass flow, often amended and criticized, correctly holds that tanslocation will not proceed efficiently until some minimal level of metabolite has accumulated in source tissues. In the present study, the leaves receiving Polaris during mid- or late afternoon were better prepared to translocate sucrose than those treated at $0630 \mathrm{~h}$. Quite obviously a Polaris-stimulated movement of sucrose could not in one day account for the juice-quality increases observed 3 weeks later; this is more plausibly explained by transport of a regulatory "factor" along with sucrose. The substance would be produced or activated in illuminated leaves and bear a decisive influence over sugar storage processes comparable to the work potential of a growth or flowering hormone. The existence of such a factor will be difficult to prove, yet the storage of sucrose in sugarcane is such an enormous and variable task that the involvement of a regulatory substance cannot be totally discounted.

In a similar vein, the loss of growth-repressing efficiency is conveniently explained by light-destruction, rather than activation, of a growth-inhibiting substance produced in leaves during the night preceding Polaris treatment. Polaris would enhance its transport to the apical meristem along with sucrose, and its optimal effect would require a Polaris application at an early-morning hour.

The above interpretations are highly theoretical, projecting as they do a hypothetical role for Polaris in transport logistics for hypothetical materials naturally accumulated and depleted within a normal daynight sequence. Their support derives from three points of evidence: a) A relationship of chemical efficiency to the amount of preillumination received on the day of application; b) growth and qualitative changes of a magnitude requiring hormone-like activities; and c) prior evidence that Polaris improves sucrose transport efficiency in the same cane variety (4).

\section{IMPLICATION FOR POLARIS FIELD EVALUATION}

Translation of greenhouse results to field conditions is hazardous owing to the loss of control over variables incident to cane culture and treatment. In this instance, the growth and qualitative results seem to justify field evaluations of Polaris on a diurnal basis. If the hypotheses offered above are valid, early-morning treatments will tend to favor the growth-retarding effects of Polaris while minimizing its ripening potential. The canopy may also receive unnecessary damage. A second consideration relates to sunlight penetration of the field canopy. Greenhouse plants, relatively uncrowded, are effectively illuminated from sunrise onward. Much of the canopy of field plants remains in twilight until incident radiation is received at a far higher angle. As a conse- 
quence, the attainment of optimal ripening efficiency may require a delay in the treatment hour, perhaps until twilight. Alternately, a light-sensitive growth inhibitor may remain viable for a longer period after sunrise.

\section{SUCROSE AND ENZYME RESPONSES}

Sucrose and acid invertase were previously described as valid indicators of chemical ripener activity that may be measured in plantlets only a few weeks old (2). In the present study both parameters were very markedly and characteristically altered by Polaris, but the effects were essentially independent of the chemical's time of application (tables 4 and 5). Of the enzymes measured, only foliar trehalase was significantly affected both by Polaris and by the hour of its reception (table 5). The enzyme's work capacity was significantly increased by Polaris applied at $0630 \mathrm{~h}$ and further increased by delaying treatment until $1230 \mathrm{~h}$ or later. Moreover, the cumulative effect of Polaris plus delayed treatment time was removed by darkening the plants throughout the following day. Furthermore, an almost total repression of trehalase was produced in immature storage tissues by all Polaris treatments. This parameter thus reflects in summation the main points brought out in this study, that is, the existence of discrete ripener activities in leaf and stem tissues, the importance of leaf preillumination, a continuing influence of differential application time some 21 days thereafter, and a post-treatment darkening effect not clearly brought out by any other parameter. Speculation on the relationship of trehalase to the efficiency of Polaris action must await further evidence.

\section{RESUMEN}

Plantas inmaturas de caña de azúcar, sembradas en arena, se sometieron a un tratamiento con Polaris (N,N-bis [fosfonometil] glicina) en distintas horas del día. Las plantas se cosecharon 21 dias más tarde. Se obtuvieron variaciones significativas en crecimiento y calidad en relación con la cantidad de luz que las plantas recibieron antes de la recepción de Polaris. La eficiencia madurativa mejoró progresivamente al retrasar el tiempo de aplicación de las $0630 \mathrm{~h}$ a las $1630 \mathrm{~h}$. La supresión del crecimiento disminuyó al retrasar la aplicación hasta las $1830 \mathrm{~h}$. Estas tendencias no se alteraron cuando las plantas se mantuvieron a obscuras durante el siguiente dia. La sacarosa y la invertasa ácida revelaron una sensibilidad general a Polaris, pero no así a la hora de aplicación.

\section{LITERATURE CITED}

1. Alexander, A. G., and Montalvo-Zapata. R., Relationships of light to enzyme and sucrose transformations in sugarcane treated with Paraquat, J. Agr. Univ. P.R. 54 (2): $264-96,1970$.

2. $\longrightarrow$ and $\longrightarrow$, Studies on the activity of C.P.41845 in early-juvenile sugarcane, Crop Sci. 12: 677-80, 1972.

3. - and - Evaluation of chemical ripeners for sugarcane having constant nitrogen and water regimes. I. Growth, quality and enzymic responses of nine potential 
ripeners, Tropical Agr. 49: 35-44, 1973.

4. — and Biddulph, O., Effects of growth-regulatory chemicals on the action spectra for ${ }^{14} \mathrm{C}$ assimilation and transport in sugarcane leaves, J. Agr. Univ. P.R. 59 (1): 15-25, 1975.

5. - and - Action spectra for ${ }^{14} \mathrm{C}$ assimilation and transport in Saccharum spp., Am. Soc. Agron., Southern Region Meeting (Abstracts), February 1975.

6. Anonymous, Entering the age of plant growth regulators, Farm Chemicals 138 (3): $15-27,1975$.

7. Borthwick, H., The biological significance of phytochrome. Chapter 2 in: Phytochrome. Proceedings of a symposium held at Eretria, Greece, September 1971. K. Mitrakos and W. Shropshire, Jr. (Eds.), Academic Press, London and New York, 1972.

8. Nickell, L. G., and Takahashi, D. T., Field studies with sugarcane ripeners in Hawaii1974, Haw. Sugar Technol. Rept., pp. 85-90, 1974.

9. Phatak, S. C., and Stephenson, G. R., Influence of light and temperature on Metribuzin phytotoxicity to tomato, Can. J. Plant Sci. 53 (4): 843-7, 1973.

10. Rostron, H., Some effects of environment, age and growth regulating compounds on the growth, yield and quality of sugarcane in Southern Africa, PhD thesis, University of Natal, 1975. 